\title{
Risk assessment and rehabilitation potential of a millennium city dumpsite in Sub-Saharan Africa
}

\author{
O.O. Ojuri ${ }^{\text {a }}$, F.O. Ayodele ${ }^{\mathrm{b}}$, O.E. Oluwatuyi ${ }^{\mathrm{c}, *}$ \\ ${ }^{a}$ Department of Civil and Environmental Engineering, Federal University of Technology Akure, Ondo State, Nigeria \\ ${ }^{\mathrm{b}}$ Department of Civil Engineering, The Federal Polytechnic Ado-Ekiti, Ekiti State, Nigeria \\ ${ }^{\mathrm{c}}$ Department of Civil Engineering, Landmark University, Omu-Aran, Kwara State, Nigeria
}

\section{A R T I C L E I N F O}

\section{Article history:}

Received 3 November 2017

Revised 19 February 2018

Accepted 1 March 2018

Available online 13 March 2018

\section{Keywords:}

Dumpsites

Integrated Risk Based Approach (IRBA)

Rehabilitation potential

Risk Index (RI)

Solid waste management

Sustainable landfill

\begin{abstract}
A B S T R A C T
Management of the ever-increasing generated solid waste had been a difficulty for state governments in Nigeria. The high costs connected to this waste management which had encumbered the state budget, ignorance or lack of understanding of resourceful waste management and insensitivity to environmental concerns may have led to partial neglect of this sector. This research paper is aimed at evaluating the rehabilitation potential and the risk level of Igbatoro dumpsite, an Ondo state-managed waste dumpsite which predominantly receives the waste of Akure and its environs. In determining rehabilitation/reconstruction potentials and assessing the risk of the dumpsite, an Integrated Risk Based Approach (IRBA) was considered. The Risk Index (RI) was calculated from the addition of the sensitivity index output with the attribute weightage of the twenty-seven (27) parameters studied. A total risk index of 571.58 was obtained for Igbatoro dumpsite indicating moderate hazard evaluation. Questionnaires distributed to dwellers around the dumpsite also showed that $83.6 \%$ of those interviewed agreed that the present management of the dumpsite is poor while $81.8 \%$ supported rehabilitation of the dumpsite. Hence, reconstruction of the Igbatoro dumpsite to an endurable and controlled landfill is hereby recommended.
\end{abstract}

(c) 2018 Elsevier Ltd. All rights reserved.

\section{Introduction}

An arduous environmental challenge facing local authorities in many countries (most especially the developing ones) all over the world is the management of the ever-increasing and diverse municipal solid wastes (MSW). Among factors contributing to increase in MSW in developing countries are increment in population levels, swift urbanization, flourishing economy and improvement in living standards (Ağdă̆, 2009; Minghua et al., 2009; Turan et al., 2009). The state/local governments in Nigeria are usually responsible for provision of effective and efficient waste management system in their cities to inhabitants. However, they face challenges in providing such (Sujauddin et al., 2008) mainly due to lack of organization, system multi dimensionality and complexity (Burnley, 2007; Guerrero et al., 2013). In developing countries additional factors challenging waste management include ignorance, dearth of sufficient policies and empowered legislation, political interference, lack of man, machine and money power (Agunwamba, 1998; Al-Khatib et al., 2015; Henry et al., 2006).

\footnotetext{
* Corresponding author.

E-mail address: oluwatuyi.opeyemi@lmu.edu.ng (O.E. Oluwatuyi).
}

Apart from disposal into flowing water and incineration, a common method of eliminating MSW in developing countries is disposal in open dumpsites (Ali et al., 2014; Nnaji, 2015; Solomon, 2009). Wastes in dumpsites are exposed and uncontrolled owing to lack of daily cover. Environmental deterioration, public health risks and other socio-economic problems are obvious consequences of mismanaging dumpsites in Nigeria (Abah and Ohimain, 2010). Besides groundwater pollution (Akinbile and Yusoff, 2011; Longe and Balogun, 2010; Oyelami et al., 2013), dumpsites are anthropogenic sources of heavy metals contamination in soil (Odai et al., 2008; Ojuri et al., 2016). All these have a negative effect on environmental quality (Biswas et al., 2010; Calvo et al., 2005; Oluwatuyi and Ojuri, 2017). Presently various countries have noticed that their waste management method do not suit sustainable development goals. Hence the need to depart from options of traditional waste management to integrated approaches of waste management (Abu Qdais, 2007). An integrated approach to waste management would overcome the challenges in developing countries. It will also reduce mortality rates and promote environmental health.

A first step to this integrated approach is the rehabilitation of dumpsites (especially those with high rehabilitation potential), 
dumpsite rehabilitation is the restoration of an uncontrolled dumpsite to a controlled dumpsite for the remaining of its operational lifetime. The rehabilitation of El Yahoudia dumping site in Tunisia is a vivid example of a rehabilitated dumpsite in a developing country (Zaïri et al., 2004). While Nas and Bayram (2008) was of the opinion that rehabilitating and closing down of the dumpsite in Gumushane province in Turkey was difficult and costly, economic benefits of rehabilitation are more than the cost incurred (Ayalon et al., 2006). Study had also shown that phytoremediation could be used as form of rehabilitation to dumpsites (Nagendran et al., 2006). In planning and initiation of dumpsite rehabilitation, evaluation of the relative health and environment hazards associated with the existing dumpsite should be adequately carried out, as it is key in recommending a suitable methodology. The objective of this paper is to evaluate the pollution risks and rehabilitation potential of the Igbatoro dumpsite using the Integrated Risk Based Approach (IRBA) suggested by Kurian et al. (2005). Steps for further improvement of the dumpsite were recommended.

\section{Study area (Igbatoro dumpsite)}

The study area is the open dumpsite of Ondo State Waste Management Authority (OSWMA) Yard situated in Igbatoro Road, Akure, Ondo State, South-western Nigeria. The dumpsite is about $4.5 \mathrm{~km}$ from the Old Owena motel (now Shoprite) with the nearest village (called Imafon) located in the upwind direction of the site about $1.6 \mathrm{~km}$ from the dumpsite. The underlying soil of the dumpsite are predominantly sand with silty content. The dumpsite receives more than 100,000 metric tons of wastes per year. It is the most active dumpsite in the state, as it receives wastes from the city of Akure and its environs. Akure is located on latitude $7^{\circ} 58^{\prime} 0^{\prime \prime} \mathrm{N}$ and Longitude $5^{\circ} 18^{\prime} 0^{\prime \prime} \mathrm{E}$ with a tropical humid climate and two distinct seasons (rain and dry), while its average annual rainfall ranges between $1405 \mathrm{~mm}$ and $2400 \mathrm{~mm}$. The main parent material of the soil is crystalline basement complex rocks, it is made up of ferruginous tropical soils. A sandy surface horizon underlain by a weakly developed clayey, mottled and occasionally concretionary sub-soil are main features of soil from the study area. The study area map is shown in Fig. 1 and a pictorial view of the dumpsite is shown in Fig. 2.

\section{Materials and method}

\subsection{Soil sampling and testing methods}

Soil samples were obtained randomly within the dumpsite at six (6) different locations as shown in Fig. 1(b). The method used for the sample collection is the trial pit method. Each pit was sunk by hand excavation with the aid of digger and shovel. Disturbed and relatively undisturbed samples were collected from the 1.2 $\mathrm{m} \times 1.2 \mathrm{~m}$ pit at varying depths of $0.5 \mathrm{~m}, 1.0 \mathrm{~m}$ and $1.5 \mathrm{~m}$. Soil were sampled at all three depths for each of the six locations except for two locations (location 5 and 6 ) where soil was not sampled at depth $1.5 \mathrm{~m}$ because of the rock present.

Basic geotechnical tests namely specific gravity, particle size distribution, Atterberg limits were performed on the soil samples in accordance to BS 1377(1990). Classification of the collected samples were done according to the American Association of State Highway and Transportation Officials (AASHTO) and Unified Soil Classification System (USCS). Permeability test was also conducted on the relatively undisturbed soil samples in accordance to the method described by Das (2002). The laboratory tests were conducted at the Soil Mechanics laboratory of The Federal Polytechnic Ado-Ekiti, Nigeria.

\subsection{Water sampling and analytical methods}

Three (3) existing hand-dug wells with approximate depths of $5.7 \mathrm{~m}, 7.65 \mathrm{~m}$ and $8.35 \mathrm{~m}$ in basement formation located within approximate distance of $12.4 \mathrm{~m}, 11.4 \mathrm{~m}$ and $9.6 \mathrm{~m}$ respectively away from the perimeter boundary of the dumpsite were used as sampling points for groundwater quality. The analyses carried out at the Quality Control laboratory of the Ondo State Water Corporation covered the physical, chemical and microbiological parameters of water samples. The physical parameters tested included appearance, color, taste, odour, turbidity, conductivity and temperature. The chemical parameters tested were $\mathrm{pH}$, Total

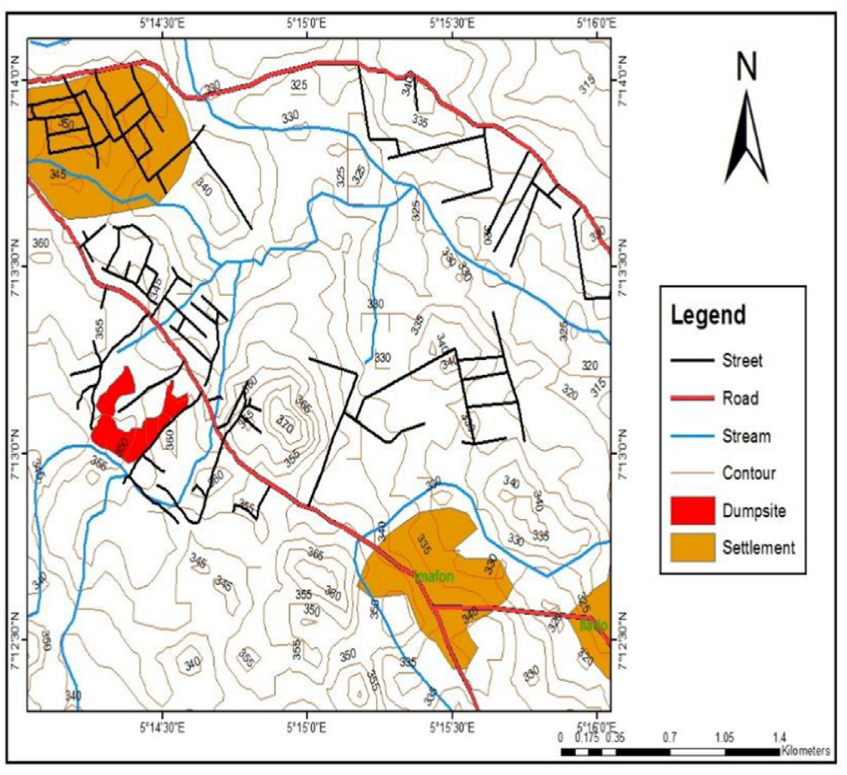

(a)

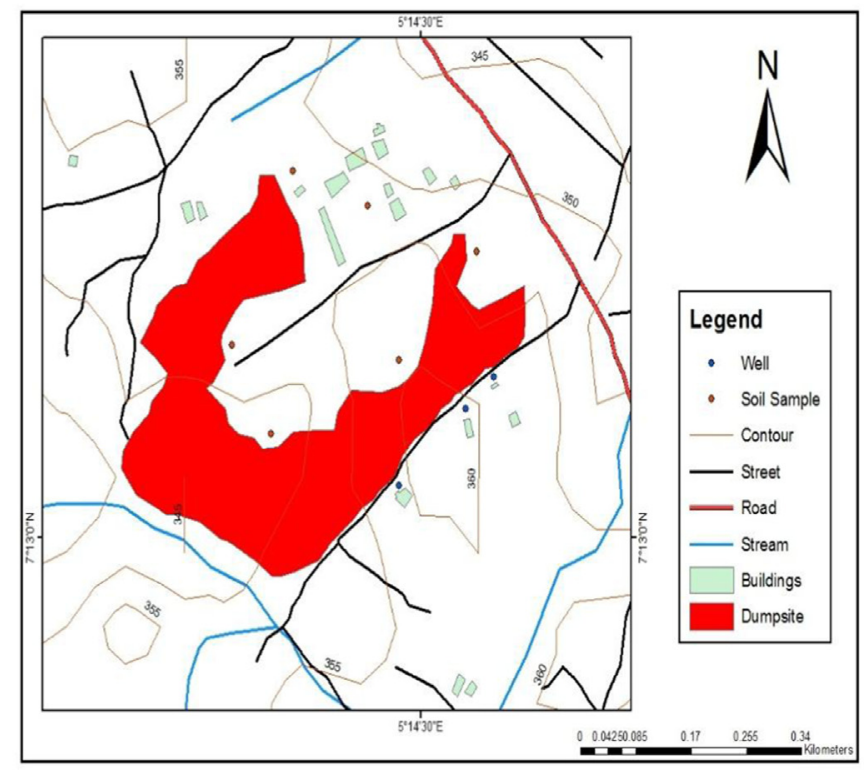

(b)

Fig. 1. Map showing (a) the existing open dumpsite and (b) existing dumpsite and sampling points. 


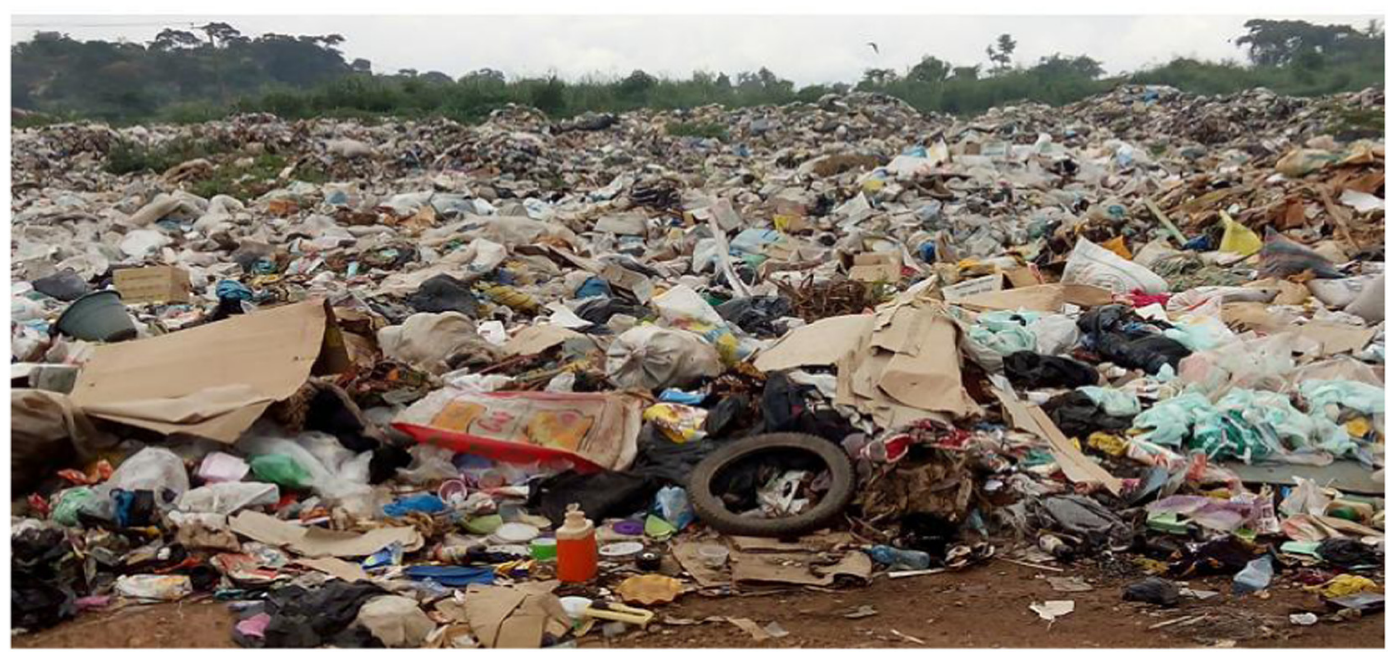

Fig. 2. View of the Igbatoro dumpsite.

Dissolved Solid (TDS), total alkalinity, total hardness, calcium hardness, magnesium hardness, chloride, nitrate, nitrite, calcium, magnesium, total iron and manganese. The microbiological parameters included coliforms, aerobic mesophilic count and $\mathrm{H}_{2} \mathrm{~S}$ paper strip.

Appearance and color of the water samples was determined using hazen disk comparator while the taste and odour were done by physical observation. A multipurpose analytical instrument (H193703 PH-028) was used to analyze turbidity and conductivity while a digital thermometer was used to measure the temperature. Lovibond comparator 2000+ was used to determine the $\mathrm{pH}$ of the water samples, the multipurpose analytical instrument (H193703 PH-028) was also used to determine the Total Dissolved Solids (TDS) gravimetrically. Samples were analyzed for total alkalinity, chloride, nitrate, nitrite, total hardness, calcium hardness and magnesium hardness using titration methods adopted by APHA (1995). Atomic absorption spectrophotometer (Phoenix-986) was used to determine the concentration of calcium, magnesium, total iron and manganese. The microbiological analysis was done in the laboratory to determine the presence of coliforms, aerobic mesophilic count and $\mathrm{H}_{2} \mathrm{~S}$ paper strip using multiple tube technique described by Ademoroti (1996).

\subsection{Leachate sampling and analytical methods}

Three (3) leachate samples were collected from a shallow pit dug with the aid of digger and shovel at points on the circumference of three (3) carefully selected circular section mapped out from the entire dumpsite area. The points were relatively low to the centre of each circular area. Total dissolved Solid (TDS), biological oxygen demand (BOD) and chemical oxygen demand (COD) were performed on the leachate samples. The method of Ademoroti (1996) was adopted for the determination of these tests. The biological oxygen demand (BOD) was determined by getting the difference between the dissolved oxygen on the first day $\left(\mathrm{DO}_{1}\right)$ and dissolved oxygen on the fifth day $\left(\mathrm{DO}_{5}\right)$.

\subsection{Waste sampling}

Six (6) samples of wastes were sampled from the dumpsite using waste sampling procedure by La Cour Jansen et al. (2004). The moisture (water) content of the sampled waste was calculated as described by Feng et al. (2017). Other parameters related to waste were calculated from data obtained from literature.

\subsection{Other dumpsite data}

Some other data obtained from the dumpsite include: annual rainfall; the distance between dumpsite and the closest source of water supply; cross-sectional area of dumpsite; depth of waste filling; depth of ground water; distance between dumpsite and critical habitats such as reserved forest and wetlands; distance between dumpsite and nearest airport, distance between dumpsite and surface water body, distance between dumpsite and nearest village in the predominant wind, distance between dumpsite and city.

The annual rainfall data of the dumpsite was obtained from the climate hazards group infrared precipitation with station data (CHIRPS). The distances were obtained using ArcGIS for information processing in a Geographical Information System (GIS) environment.

\subsection{Survey}

The use of questionnaires had been one of the major research method extensively used in waste management (Yuan and Shen, 2011). 110 questionnaires backed up with an interview guide were randomly distributed in various locations around the dumpsites. The locations were Imafon Village, Scab filling station street and Ala-Igbatoro road (two streets adjoining the dumpsite). Statistical analysis was carried out on the data collected using Statistical Package for Social Sciences (SPSS) program (version 17). Chisquare test of significance was carried out at a $5 \%$ level of significance.

\subsection{Decision tool (Integrated Risk Based Approach, IRBA)}

Integrated Risk Based Approach (IRBA) is a decision-making tool developed in 2005 for dumpsite rehabilitation including sites with high health risk, maximum environmental impacts and sensitive public concerns. This decision tool, a table as shown in Table 1 was developed and described by Kurian et al. (2005). The risk index for the dumpsite was calculated as the cumulative sum of multiplied values for each attribute weightage and sensitivity index. The risk index value was assessed using Table 2 to find the hazard level and the recommended action was proposed. IRBA decisionmaking tool assay at furnishing Government and other implementing authorities' guidance for prioritizing actions related to dumpsite rehabilitation. 
Table 1

Attribute weightage and sensitivity.

\begin{tabular}{|c|c|c|c|c|c|c|}
\hline \multirow[t]{2}{*}{$\mathrm{S} / \mathrm{N}$} & \multirow[t]{2}{*}{ Attribute } & \multirow{2}{*}{$\begin{array}{l}\text { Attribute } \\
\text { weightage }\end{array}$} & \multicolumn{4}{|c|}{ Sensitivity index } \\
\hline & & & $0.00-0.25$ & $0.25-0.50$ & $0.50-0.75$ & $0.75-1.00$ \\
\hline \multicolumn{7}{|c|}{ I - Site specific criteria } \\
\hline 1. & Distance from nearest water supply source (m) & 69 & $>5000$ & $2500-5000$ & $1000-2500$ & $<1000$ \\
\hline 2. & Depth of filling of waste (m) & 64 & $<3$ & $3-10$ & $10-20$ & $>20$ \\
\hline 3. & Area of the dumpsite (Ha) & 61 & $<5$ & $5-10$ & $10-20$ & $>20$ \\
\hline 4. & Groundwater depth (m) & 54 & $>20$ & $10-20$ & $3-10$ & $<3$ \\
\hline 5. & Permeability of soil $\left(1 \times 10^{-6} \mathrm{~cm} / \mathrm{s}\right)$ & 54 & $<0.1$ & $1-0.1$ & $1-10$ & $>10$ \\
\hline 6. & Groundwater quality & 50 & Not a concern & Potable & $\begin{array}{l}\text { Potable if no } \\
\text { alternative }\end{array}$ & Non-potable \\
\hline 7. & $\begin{array}{l}\text { Distance to critical habitats such as wetlands and } \\
\text { reserved forest }(\mathrm{km})\end{array}$ & 46 & $>25$ & $10-25$ & $5-10$ & $<5$ \\
\hline 8. & Distance to the nearest airport $(\mathrm{km})$ & 46 & $>20$ & $10-20$ & $5-10$ & $<5$ \\
\hline 9. & Distance from surface water body (m) & 41 & $>8000$ & $1500-8000$ & $500-1500$ & $<500$ \\
\hline 10. & Type of underlying soil (\% clay) & 41 & $>50$ & $30-50$ & $15-30$ & $0-15$ \\
\hline 11. & Life of the site for future use (years) & 36 & $<5$ & $5-10$ & $10-20$ & $>20$ \\
\hline 12. & Type of waste (MSW/HW) & 30 & $100 \%$ MSW & $75 \% \mathrm{MSW}+25 \% \mathrm{HW}$ & $50 \% \mathrm{MSW}+50 \% \mathrm{HW}$ & $>50 \% \mathrm{HW}$ \\
\hline 13. & Total quantity of waste at site (tons) & 30 & $<10^{4}$ & $10^{4}-10^{5}$ & $10^{5}-10^{6}$ & $>10^{6}$ \\
\hline 14. & Quantity of wastes disposed (tons/day) & 24 & $<250$ & $250-500$ & $500-1000$ & $>1000$ \\
\hline 15. & $\begin{array}{l}\text { Distance to the nearest village in the predominant } \\
\text { wind }(\mathrm{m})\end{array}$ & 21 & $>1000$ & $600-1000$ & $300-600$ & $<300$ \\
\hline 16. & Flood proneness (flood period in years) & 16 & $>100$ & $30-100$ & $10-30$ & $<10$ \\
\hline 17. & Annual rainfall at site (cm/year) & 11 & $<25$ & $25-125$ & $125-250$ & $>250$ \\
\hline 18. & Distance from the city $(\mathrm{km})$ & 7 & $>20$ & $10-20$ & $5-10$ & $<5$ \\
\hline 19. & Public acceptance & 7 & $\begin{array}{l}\text { No public } \\
\text { concerns }\end{array}$ & $\begin{array}{l}\text { Accepts dump } \\
\text { rehabilitation }\end{array}$ & $\begin{array}{l}\text { Accepts dump } \\
\text { closure }\end{array}$ & $\begin{array}{l}\text { Accepts dump closure } \\
\text { and remediation }\end{array}$ \\
\hline 20. & Ambient air quality $-\mathrm{CH}_{4}(\%)$ & 3 & $<0.01$ & $0.05-0.01$ & $0.5-0.1$ & $>0.1$ \\
\hline \multicolumn{7}{|c|}{ II - Related to characteristics of waste at dumpsite } \\
\hline 21. & Hazardous contents in waste (\%) & 71 & $<10$ & $10-20$ & $20-30$ & $>30$ \\
\hline 22. & Biodegradable fraction of waste at site (\%) & 66 & $<10$ & $10-30$ & $30-60$ & $60-100$ \\
\hline 23. & Age of filling (years) & 58 & $>30$ & $20-30$ & $10-20$ & $<10$ \\
\hline 24. & Moisture of waste at site (\%) & 26 & $<10$ & $10-20$ & $20-40$ & $>40$ \\
\hline \multicolumn{7}{|c|}{ III - Related to leachate quality } \\
\hline 25. & BOD of leachate $(\mathrm{mg} / \mathrm{l})$ & 36 & $<30$ & $30-60$ & $60-100$ & $>100$ \\
\hline 26. & COD of leachate $(\mathrm{mg} / \mathrm{l})$ & 19 & $<250$ & $250-350$ & $350-500$ & $>500$ \\
\hline 27. & TDS of leachate $(\mathrm{mg} / \mathrm{l})$ & 13 & $<2100$ & $2100-3000$ & $3000-4000$ & $>4000$ \\
\hline
\end{tabular}

Source: Kurian et al. (2005).

Table 2

Criteria for hazard evaluation based on the risk index.

\begin{tabular}{|c|c|c|c|}
\hline $\mathrm{S} / \mathrm{N}$ & Overall score & Hazard evaluation & Recommended action \\
\hline 1 & $750-1000$ & Very high & Close the dump with no more landfilling in the area. Take remedial action to mitigate the impacts \\
\hline 2 & $600-749$ & High & Close the dump with no more landfilling in the area. Remediation is optional \\
\hline 3 & $450-599$ & Moderate & Immediate Rehabilitation of the dumpsite into sustainable landfill \\
\hline 4 & $300-499$ & Low & Rehabilitate the dumpsite into sustainable landfill in a phased manner \\
\hline 5 & $<300$ & Very low & Potential Site for future landfill \\
\hline
\end{tabular}

Source: Kurian et al. (2005).

\section{Results and discussion}

\subsection{Soil test results}

The results of the soil tests conducted on the soil sample from the dumpsite detailing the properties of the soil were shown in Table 3. All soil samples with the exception of $2 \mathrm{~B}, 2 \mathrm{C}$ and $3 \mathrm{C}$ had less than $50 \%$ of their particle pass through BS sieve $75 \mu \mathrm{m}$. The soil samples were mostly A-7-6 and A-2-6 soils, while samples $1 \mathrm{~A}, 1 \mathrm{~B}$ and $3 A$ were A-2-4, A-6 and A-2-7 soils respectively according to AASHTO classification. Samples were mostly clayey sand (SC) and fat clay $(\mathrm{CH})$, with sample $1 \mathrm{~A}$ classified as silty sand (SM) according to the USCS classification. Sample 1A confirmed the observation made on getting to the dumpsite, that the underlying soil of the dumpsite are predominantly sand with silty content. The clay fraction of the soil samples ranges from 0 to $10 \%$, this was lower than the $\geq 20 \%$ of clay specified for a clay liner material (Ojuri, 2015). Unlike some Nigerian lateritic clay soils that could be used as hydraulic barriers (Ojuri et al., 2017), the coefficient of permeability $(k)$ values for the Igbatoro dumpsite soil ranges from $1.31 \times 10^{-3}$ to $8.1 \times 10^{-4} \mathrm{~cm} / \mathrm{s}$. These values were higher than $1 \times 10^{-9} \mathrm{~m} / \mathrm{s}$ or $1 \times 10^{-7} \mathrm{~cm} / \mathrm{s}$, the maximum coefficient of permeability value for a liner material (Ojuri and Oluwatuyi, 2017).

\subsection{Groundwater properties}

The results of the physical, chemical and microbiological tests conducted on water samples from the three wells in comparison with World Health Organization, WHO (2011) standard are presented in Table 4. The physical parameters which include appearance, color, taste, odour, turbidity, conductivity and temperature were in conformity with WHO (2011) guideline for drinking water quality. Potable water among others must be colorless, odourless, tasteless, and free from chemical impurities, unpleasant and pathogenic organism. 
Table 3

Properties of underlying soil sample of Igbatoro dumpsite.

\begin{tabular}{|c|c|c|c|c|c|c|c|c|c|c|c|c|c|c|c|c|c|c|}
\hline \multirow[t]{2}{*}{ Property } & \multicolumn{18}{|c|}{ Sampling symbols } \\
\hline & $1 \mathrm{~A}$ & 1B & $1 C$ & $2 \mathrm{~A}$ & $2 \mathrm{~B}$ & $2 \mathrm{C}$ & $3 A$ & 3B & $3 C$ & $4 \mathrm{~A}$ & $4 \mathrm{~B}$ & $4 C$ & $5 \mathrm{~A}$ & $5 \mathrm{~B}$ & $5 C$ & $6 \mathrm{~A}$ & $6 B$ & $6 C$ \\
\hline \multicolumn{19}{|l|}{ Particle size distribution } \\
\hline$\%<0.075 \mathrm{~mm}$ & 18.8 & 36.8 & 49.7 & 42.8 & 58.2 & 56.1 & 15.9 & 44.3 & 61.1 & 33.0 & 47.1 & 48.8 & 18.2 & 22.6 & ND & 32.7 & 43.3 & ND \\
\hline$\%<0.425 \mathrm{~mm}$ & 36.2 & 51.3 & 66.3 & 50.0 & 67.1 & 68.3 & 20.5 & 55.7 & 71.9 & 64.3 & 63.0 & 66.9 & 27.9 & 33.7 & ND & 47.8 & 58.1 & ND \\
\hline$\%<2.00 \mathrm{~mm}$ & 59.1 & 76.2 & 86.9 & 66.5 & 85.0 & 89.9 & 32.7 & 76.9 & 88.9 & 93.1 & 84.7 & 91.4 & 39.2 & 47.9 & ND & 67.0 & 79.0 & ND \\
\hline \%Clay $(<0.002 \mathrm{~mm})$ & 2.3 & 6.8 & 4.3 & 10 & 4.0 & 3.8 & 0.64 & 3.4 & 5.5 & 1.9 & 4.5 & 0.0 & 0.0 & 4.82 & ND & 1.2 & 0.0 & ND \\
\hline \%Sand $(0.075-4.75 \mathrm{~m})$ & 61.9 & 56.6 & 46.9 & 35.8 & 35.7 & 41.8 & 43.4 & 45.0 & 34.8 & 64.3 & 45.4 & 49.4 & 61.7 & 40.5 & ND & 45.6 & 43.0 & ND \\
\hline$\%$ Gravel $(>4.75 \mathrm{~mm})$ & 19.3 & 6.63 & 3.41 & 21.4 & 6.14 & 2.12 & 40.7 & 10.7 & 4.11 & 2.72 & 7.48 & 1.83 & 43.5 & 36.9 & ND & 21.7 & 13.7 & ND \\
\hline \multicolumn{19}{|l|}{ Physical properties } \\
\hline LL (\%) & 19.5 & 38.5 & 45.5 & 61.9 & 58.0 & 61.0 & 43.2 & 54.0 & 51.9 & 25.9 & 46.8 & 53.0 & 29.5 & 34.0 & ND & 39.0 & 41.5 & ND \\
\hline PL (\%) & 12.6 & 19.6 & 18.1 & 24.8 & 25.7 & 26.3 & 20.0 & 24.5 & 27.1 & 10.5 & 20.4 & 26.6 & 15.6 & 16.9 & ND & 19.4 & 21.9 & ND \\
\hline LS (\%) & 2.1 & 6.4 & 7.9 & 8.6 & 14.3 & 10.7 & 7.1 & 5.0 & 10.0 & 3.6 & 13.6 & 10.0 & 5.7 & 7.1 & ND & 7.1 & 7.1 & ND \\
\hline PI (\%) & 6.9 & 18.9 & 27.4 & 37.1 & 32.3 & 34.7 & 23.2 & 29.5 & 24.8 & 15.4 & 26.4 & 26.4 & 13.9 & 17.1 & ND & 19.6 & 19.6 & ND \\
\hline $\mathrm{G}_{\mathrm{S}}$ & 2.63 & 2.60 & 2.57 & 2.10 & 2.17 & 2.66 & 2.64 & 2.55 & 2.22 & 2.58 & 2.56 & 2.58 & 2.54 & 2.28 & ND & 2.63 & 2.57 & ND \\
\hline \multicolumn{19}{|c|}{ Engineering property and soil classification } \\
\hline $\mathrm{k}(\mathrm{cm} / \mathrm{s}) 1 \times 10^{-3}$ & 2.47 & 0.41 & 0.81 & 0.40 & 0.81 & 0.49 & 3.60 & 2.21 & 0.22 & 2.50 & 0.20 & 3.03 & 3.24 & 0.40 & ND & 2.40 & 1.31 & ND \\
\hline AASHTO & A-2-4 & A-6 & A-7-6 & A-7-6 & A-7-6 & A-7-6 & A-2-7 & A-7-6 & A-7-6 & A-2-6 & A-7-6 & A-7-6 & A-2-6 & A-2-6 & ND & A-2-6 & A-7-6 & ND \\
\hline USCS & SM & SC & SC & SC & $\mathrm{CH}$ & $\mathrm{CH}$ & SC & SC & $\mathrm{CH}$ & SC & SC & SC & SC & SC & ND & SC & SC & ND \\
\hline
\end{tabular}

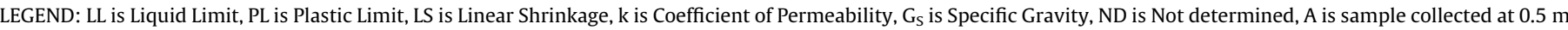
depth, B is sample collected at $1.0 \mathrm{~m}, \mathrm{C}$ is sample collected at $1.5 \mathrm{~m}$.

Table 4

Properties of water samples.

\begin{tabular}{|c|c|c|c|c|c|}
\hline \multirow[t]{2}{*}{$\mathrm{S} / \mathrm{N}$} & \multirow[t]{2}{*}{ Test } & \multicolumn{3}{|l|}{ Results } & \multirow[t]{2}{*}{ WHO limits } \\
\hline & & Well A & Well B & Well C & \\
\hline \multicolumn{6}{|c|}{ Physical parameters } \\
\hline 1 & Appearance & Clear & Clear & Clear & Clear \\
\hline 2 & Color, TCU & 0.2 & 0.08 & 0.06 & 3 \\
\hline 3 & Taste & Insipid & Insipid & Insipid & Insipid \\
\hline 4 & Odour & Odourless & Odourless & Odourless & Odourless \\
\hline 5 & Turbidity, NTU & 0.8 & 0.7 & 0.4 & 5 \\
\hline 6 & Conductivity $\mu \mathrm{mho} / \mathrm{cm}$ & $0.06 \times 10^{3}$ & $0.06 \times 10^{3}$ & $0.08 \times 10^{3}$ & $1.0 \times 10^{3}$ \\
\hline 7 & Temperature & 25.5 & 25.5 & 26 & NA \\
\hline \multicolumn{6}{|c|}{ Chemical parameters } \\
\hline 8 & $\mathrm{pH}$ & 5.8 & 5.8 & 6 & $6.5-8.5$ \\
\hline 9 & Total dissolved solid, ppm. $\mathrm{CaCo}_{3}$ & 42 & 40 & 60 & 500 \\
\hline 10 & Total alkalinity, ppm. $\mathrm{CaCo}_{3}$ & 40 & 42 & 74 & 200 \\
\hline 11 & Total Hardness, ppm. $\mathrm{CaCo}_{3}$ & 64 & 56 & 90 & 400 \\
\hline 12 & Calcium Hardness, ppm. $\mathrm{CaCo}_{3}$ & 42 & 40 & 74 & 75 \\
\hline 13 & Magnesium Hardness, ppm. $\mathrm{CaCo}_{3}$ & 22 & 16 & 16 & 30 \\
\hline 14 & Chloride, ppm. $\mathrm{Cl}$ & 34 & 21 & 27 & 200 \\
\hline 15 & Nitrate, ppm. (as N) & 0.1 & 0.12 & 0.15 & 11 \\
\hline 16 & Nitrite, ppm. (as N) & 0.07 & 0.09 & 0.11 & 1.0 \\
\hline 17 & Calcium, ppm. Ca & 16.8 & 16 & 29.6 & 75 \\
\hline 18 & Magnesium, ppm. Mg & 8.8 & 6.4 & 6.4 & 20 \\
\hline 19 & Total Iron, ppm. Fe & 0.06 & 0.08 & 0.12 & 0.3 \\
\hline 20 & Manganese, ppm. Mn & ND & ND & 0.03 & 0.1 \\
\hline \multicolumn{6}{|c|}{ Microbiological analysis } \\
\hline 21 & Coliforms, MPN/100 ml & 8 & 7 & 24 & Nil (0) \\
\hline 22 & Aerobic mesophilic count, $\mathrm{cfu} / \mathrm{ml}$ & $1.14 \times 10^{2}$ & $1.08 \times 10^{2}$ & $1.76 \times 10^{2}$ & $1.0 \times 10^{2}$ \\
\hline 23 & $\mathrm{H}_{2} \mathrm{~S}$ paper strip & $+\mathrm{LR}$ & $+\mathrm{LR}$ & $++\mathrm{MR}$ & $\{-\} N R$ \\
\hline
\end{tabular}

The chemical characteristics of the water samples showed that pH was 5.8 (for well A and well B) and 6.0 (for well C), these values were lower than the values stated by WHO (2011). The water samples were acidic, which may have been caused by presence of metals such as zinc, damaged battery cells (Lead, Mercury and alkaline) deposited on the dumpsite which had migrated downward through seepage (Akinbile and Yusoff, 2011). The total dissolved solids (TDS), total alkalinity, total hardness, calcium hardness, magnesium hardness values of the water samples from the three (3) wells are all below the limits stated by WHO (2011). Other chemical properties which include chloride, calcium, total iron, magnesium, manganese, nitrates and nitrites were also below the WHO limits.

The microbiological characteristics of samples showed that the coliforms reported in most probable number per hundred milliliters (MPN/100 ml) ranged from 7 to 24 , these values were above the WHO limit of nil (0). The increase in presence of coliforms may attributed to the waste dumping on the site. Aerobic mesophilic count values of the water sample reported in colony forming unit per milliliter $(\mathrm{cfu} / \mathrm{ml})$ range from $1.08 \times 10^{2}$ to $1.76 \times 10^{2}$ with sample from well $C$ having the highest. All samples exceeded the WHO limit of $1.0 \times 10^{2}$. The $\mathrm{H}_{2} \mathrm{~S}$ paper strip test values of water 
samples indicated that sample from well $\mathrm{C}$ is of moderate risk while samples from wells A and B carries low risk. WHO (2011) stated that $\mathrm{H}_{2} \mathrm{~S}$ paper strip test on water sample should display a 'no risk' result.

\subsection{Leachate analysis}

The results obtained from the analysis done on the three (3) leachate samples collected from a shallow pit were presented in Fig. 3. From the figure, it was observed that the total dissolved solids (TDS) ranged from $2597.00 \mathrm{mg} / \mathrm{l}$ to $3695.00 \mathrm{mg} / \mathrm{l}$. From the samples collected, sample 1 had the highest TDS value while sample 2 had the lowest. Biochemical oxygen demand (BOD) values ranged from $124.10 \mathrm{mg} / \mathrm{l}$ to $223.38 \mathrm{mg} / \mathrm{l}$, sample 1 had the highest while sample 2 had the lowest BOD value. Chemical oxygen demand (COD) for the three sampling points revealed sample 1 as the lowest COD value $(720 \mathrm{mg} / \mathrm{l})$ while sample 2 had the highest value of $880 \mathrm{mg} / \mathrm{l}$.

\subsection{Waste characteristics and other data results}

One of the requirement needed for prosperous execution of any solid waste management plan is the amount of available information on the characteristics (composition and quantities) of generated solid waste. The generation of waste in Akure was estimated at $0.54 \mathrm{~kg} /$ person/day (Abila and Kantola, 2013; Babayemi and Dauda, 2009). The volume of solid waste generated in Akure was estimated at 60,000 metric tons/year in 1996 which rose to 75,000 metric tons/year in 2006 (Akinbile and Yusoff, 2011). With the trend of population growth in Akure, the quantity of solid waste would have increased. Olanrewaju and Ilemobade (2009) asserted that solid waste in Akure consists of $70.3 \%$ domestic waste, while $18.6 \%, 6.3 \%$ and $4.8 \%$ are for commerce, agriculture and industrial waste respectively. MSW in Akure as presented in Fig. 4 showed that it is made up of $10 \%$ paper and cardboard, $54.0 \%$ food and other putrescible materials, $12.5 \%$ plastic, nylon, rubber, $4.3 \%$ metal and aluminum, 2.0\% glass, 6.0\% wood, 5.2\% textiles and leather and $6.0 \%$ of soil like waste (Ojuri and Adegoke, 2015).

Igbatoro dumpsite where all these MSW are dumped is situated in an area not susceptible to flooding. It is situated on a natural elevation higher than the adjoining land area of the dumpsite. The water-table level of the dumpsite area occurs at a depth ranging

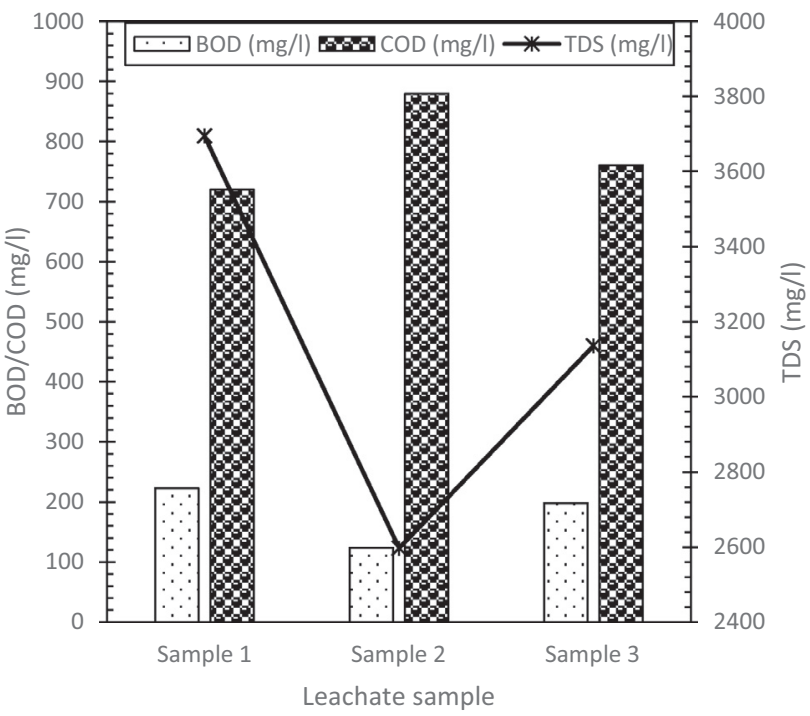

Fig. 3. Biochemical oxygen demand (BOD), chemical oxygen demand (COD) and total dissolved solids (TDS) in leachate samples.

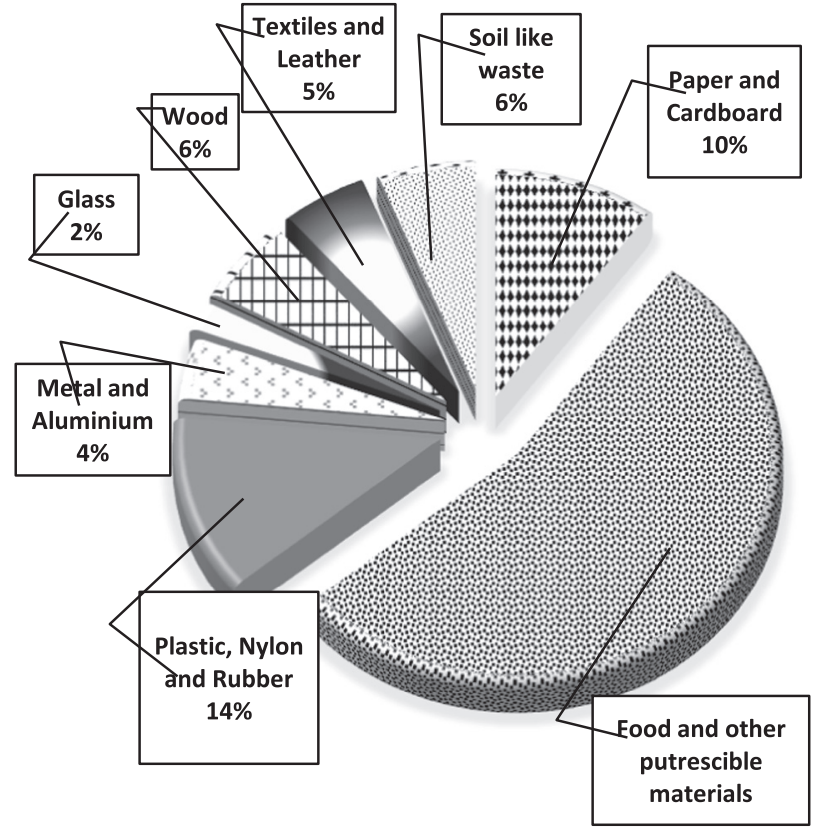

Fig. 4. Municipal Solid Waste Composition of Akure Metropolis.

from $9.6 \mathrm{~m}$ to $12.4 \mathrm{~m}$. The annual rainfall of the dumpsite is $14.44 \mathrm{~cm} /$ year, while the average moisture content of the waste samples was about $32.4 \%$ where minimum and maximum values were $17.44 \%$ and $40.57 \%$ respectively.

\subsection{Survey result}

Public acceptance is the view held by dwellers around the dumpsite and their disposition to the situation/location of the dumpsite near their place of worship, business premises and residential buildings. The result obtained from chi-square test conducted on the completed questionnaire showed that at $95 \%$ confidence interval (significance level of 0.05 ), p- value calculated was 0.492 . This means that the relationship that exist between 'action to be taken on the dumpsite' and 'location consideration' is not significant since p-value is greater than significance level of 0.05 . This indicates that dwellers support rehabilitation of the dumpsite irrespective of the distance that exist between their premises and the dumpsite. Fig. 5 which detailed the response of the dwellers

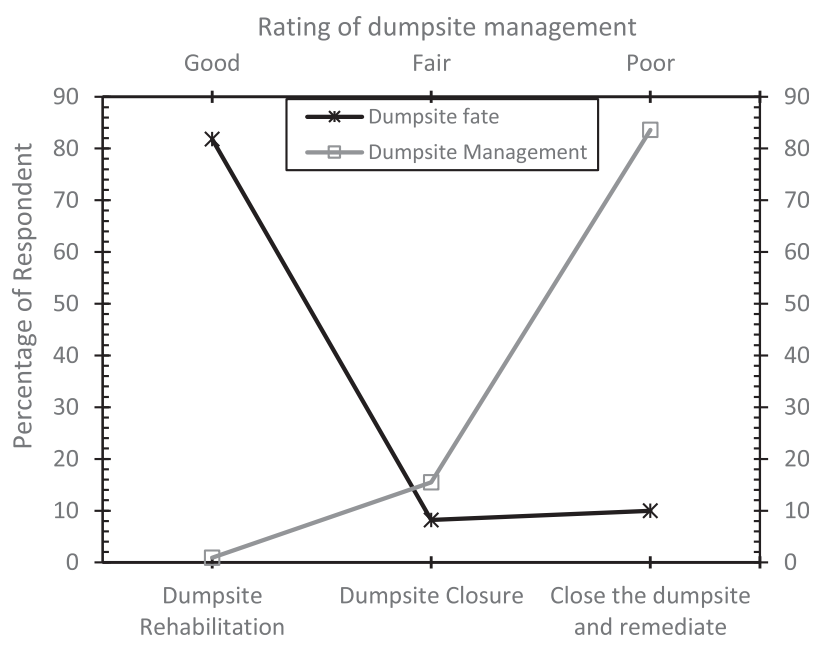

Fig. 5. Respondent views about Igbatoro dumpsite. 
Table 5

Risk index work sheet.

\begin{tabular}{|c|c|c|c|c|c|}
\hline \multirow[t]{2}{*}{$\mathrm{S} / \mathrm{N}$} & \multirow[t]{2}{*}{ Attribute (A) } & \multirow[t]{2}{*}{ Attribute weightage (B) } & \multicolumn{3}{|l|}{ Igbatoro dumpsite } \\
\hline & & & Attribute measurement $(\mathrm{C})$ & Sensitivity index (D) & Score $\left(B^{*} D\right)$ \\
\hline 1 & Distance from nearest water supply source (m) & 69 & 4010 & 0.4 & 27.6 \\
\hline 2 & Depth of filling of waste $(\mathrm{m})$ & 64 & 2.62 & 0.22 & 14.08 \\
\hline 3 & Area of the dumpsite (Ha) & 61 & 7 & 0.35 & 21.35 \\
\hline 4 & Groundwater depth (m) & 54 & 7.2 & 0.65 & 35.1 \\
\hline 5 & Permeability of soil $\left(1 \times 10^{-6}\right) \mathrm{cm} / \mathrm{s}$ & 54 & $>10$ & 1 & 54 \\
\hline 6 & Groundwater quality & 50 & Non-potable & 1 & 50 \\
\hline 7 & $\begin{array}{l}\text { Distance to critical habitats such as wetlands and reserved } \\
\text { forest }(\mathrm{km})\end{array}$ & 46 & 25.9 & 0.25 & 11.5 \\
\hline 8 & Distance to the nearest airport $(\mathrm{km})$ & 46 & 7.2 & 0.61 & 28.06 \\
\hline 9 & Distance from surface water body & 41 & $<500$ & 1 & 41 \\
\hline 10 & Type of underlying soil (\% clay) & 41 & $0-10$ & 1 & 41 \\
\hline 11 & Life of the site for future use (year) & 36 & $10-20$ years & 0.75 & 27 \\
\hline 12 & Type of waste (MSW/HW) & 30 & MSW & 0.1 & 3 \\
\hline 13 & Total quantity of waste at site (tons) & 30 & 98,425 & 0.5 & 15 \\
\hline 14 & Quantity of waste disposed (tons/day) & 24 & 236 & 0.25 & 6 \\
\hline 15 & Distance to the nearest village in the predominant wind $(\mathrm{m})$ & 21 & 1600 & 0.25 & 5.25 \\
\hline 16 & Flood proneness (flood period in years) & 16 & 0 & 0 & 0 \\
\hline 17 & Annual rainfall (cm/year) & 11 & 14.44 & 0.14 & 1.54 \\
\hline 18 & Distance from the city (km) & 7 & 7.6 & 0.63 & 4.41 \\
\hline 19 & Public acceptance & 7 & Accepts rehabilitation & 0.5 & 3.5 \\
\hline 20 & Ambient air quality $\mathrm{CH}_{4}(\%)$ & 3 & ND & ND & ND \\
\hline 21 & Hazardous contents in waste (\%) & 71 & $<10$ & 0.1 & 7.1 \\
\hline 22 & Biodegradable fraction of waste at site (\%) & 66 & 60 & 0.88 & 58.08 \\
\hline 23 & Age of filling (year) & 58 & 16 & 0.65 & 37.7 \\
\hline 24 & Moisture of waste at site (\%) & 26 & 32.4 & 0.56 & 14.56 \\
\hline 25 & BOD of leachate $(\mathrm{mg} / \mathrm{l})$ & 36 & $124.1-223.4(>100)$ & 1 & 36 \\
\hline 26 & COD of leachate $(\mathrm{mg} / \mathrm{l})$ & 19 & $720-880(>500)$ & 1 & 19 \\
\hline \multirow[t]{2}{*}{27} & TDS of leachate $(\mathrm{mg} / \mathrm{l})$ & 13 & $2597-3695$ & 0.75 & 9.75 \\
\hline & & & & $(\mathrm{RI})$ & 571.58 \\
\hline
\end{tabular}

LEGEND: RI - Risk Index; ND - Not determined.

showed that $81.8 \%$ (90 out of 110 ) supports dumpsite rehabilitation. While another $83.6 \%$ of respondents claim that the present management of waste disposed on the dumpsite is poor.

\subsection{Results for decision tool}

The attributes of Igbatoro dumpsite and their corresponding weightage are detailed in Table 5 . The attribute weightage was multiplied with the sensitivity index and the total sum was the Risk Index (RI) value of the dumpsite. The Risk Index (RI) value of Igbatoro dumpsite was 571.58 which was higher than the 452.315 obtained by Abah and Ohimain (2010) and within the range of the values obtained by Kurian et al. (2005). The RI value suggests a moderate hazard potential and need for immediate rehabilitation of the dumpsite into sustainable landfill according to criteria for hazard evaluation shown in Table 2.

\section{Conclusions and recommendations}

This paper assessed the risk associated with the continued dumping of wastes on the Igbatoro dumpsite and the potential for its rehabilitation. Several field and laboratory tests which include dumpsite reconnaissance, geotechnical tests on the dumpsite soil, groundwater physiochemical/microbiological tests and leachate analysis were conducted. Questionnaires survey were also used to determine public acceptance of the dumpsite. The test results which showed the properties of the site where the wastes were dumped, characteristics of the wastes being dumped and the quality of leachate from the dumpsite were analyzed with the IRBA model. A total risk index of 571.58 signifying moderate hazard evaluation was calculated using the IRBA model. The recommended action for dumpsite with such risk index is "immediate rehabilitation of the dumpsite into sustainable landfill".
An immediate reconstruction of the dumpsite into a sustainable landfill is recommended so as to mitigate the hazardous effects the dumpsite is posing to the environment. The coefficient of permeability values for the underlying soil were however high, ranging from $1.31 \times 10^{-3} \mathrm{~cm} / \mathrm{s}$ to $8.10 \times 10^{-4} \mathrm{~cm} / \mathrm{s}$, making it unsuitable as a landfill liner material. Waste recycling should be effectively implemented on the dumpsite. Government should also develop a guideline which will provide a framework for effective waste collection, disposal and management.

\section{Acknowledgements}

The authors would like to appreciate the support from the following Institutions: Ondo Waste Management Authority (OSWMA); Ondo State Water Corporation, Akure Ondo State; Department of Civil Engineering, Federal Polytechnic Ado-Ekiti and Department of Civil and Environmental Engineering, Federal University of Technology Akure Nigeria.

\section{References}

Abah, S.O., Ohimain, E.I., 2010. Assessment of dumpsite rehabilitation potential using the integrated risk based approach: a case study of eneka, Nigeria. World Appl. Sci. J. 8, 436-442.

Abila, B., Kantola, J., 2013. Municipal solid waste management problems in Nigeria: Evolving knowledge management solution. Int. J. Environ. Ecol. Geol. Geophys. Eng. 7, 172-177.

Abu Qdais, H.A., 2007. Techno-economic assessment of municipal solid waste management in Jordan. Waste Manage. 27, 1666-1672. https://doi.org/ 10.1016/j.wasman.2006.08.004.

Ademoroti, C.M.A., 1996. Standard Method for Water and Effluent Analysis. Foludex Press Ltd., Ibadan.

Ağdağ, O.N., 2009. Comparison of old and new municipal solid waste management systems in Denizli, Turkey. Waste Manage. 29, 456-464. https://doi.org/ 10.1016/j.wasman.2008.01.012.

Agunwamba, J., 1998. Solid waste management in Nigeria: Problems and issues. Environ. Manage. 22, 849-856. https://doi.org/10.1007/s002679900152. 
Akinbile, C.O., Yusoff, M.S., 2011. Environmental impact of leachate pollution on groundwater supplies in akure, Nigeria. Int. J. Environ. Sci. Dev. 2, 81-86.

Al-Khatib, I.A., Kontogianni, S., Abu Nabaa, H., Alshami, N., Al-Sari', M.I., 2015. Public perception of hazardousness caused by current trends of municipal solid waste management. Waste Manage. 36, 323-330. https://doi.org/10.1016/j. wasman.2014.10.026.

Ali, S.M., Pervaiz, A., Afzal, B., Hamid, N., Yasmin, A., 2014. Open dumping of municipal solid waste and its hazardous impacts on soil and vegetation diversity at waste dumping sites of Islamabad city. J. King Saud Univ. - Sci. 26, 59-65. https://doi.org/10.1016/j.jksus.2013.08.003.

American Public Health Association, APHA 1995. Standard methods for the examination for water and wastewater.

Ayalon, O., Becker, N., Shani, E., 2006. Economic aspects of the rehabilitation of the Hiriya landfill. Waste Manage. 26, 1313-1323. https://doi.org/10.1016/j. wasman.2005.09.023.

Babayemi, J.O., Dauda, K.T., 2009. Evaluation of solid waste generation, categories and disposal options in developing countries: A case study of Nigeria. J. Appl. Sci. Environ. Manage. 13, 83-88. https://doi.org/10.4314/jasem.v13i3.55370.

Biswas, A.K. Kumar, S., Babu, S.S., Bhattacharyya, J.K., Chakrabarti, T., 2010. Studies on environmental quality in and around municipal solid waste dumpsite. Resour. Conserv. Recycl. 55, 129-134. https://doi.org/10.1016/j. resconrec.2010.08.003.

BS 1377, 1990. Methods of test for Soils for civil engineering purposes.

Burnley, S.J., 2007. A review of municipal solid waste composition in the United Kingdom. Waste Manage. 27, 1274-1285. https://doi.org/10.1016/j. wasman.2006.06.018.

Calvo, F., Moreno, B., Zamorano, M., Szanto, M., 2005. Environmental diagnosis methodology for municipal waste landfills. Waste Manage. 25, 768-779. https://doi.org/10.1016/j.wasman.2005.02.019.

Das, B.M., 2002. Soil Mechanics Laboratory Manual. Oxford University Press, New York.

Feng, S.J., Gao, K.W., Chen, Y.X., Li, Y., Zhang, L.M., Chen, H.X., 2017. Geotechnical properties of municipal solid waste at Laogang Landfill, China. Waste Manage. 63, 354-365. https://doi.org/10.1016/j.wasman.2016.09.016.

Guerrero, L.A., Maas, G., Hogland, W., 2013. Solid waste management challenges for cities in developing countries. Waste Manage. 33, 220-232. https://doi.org/ 10.1016/j.wasman.2012.09.008.

Henry, R.K., Yongsheng, Z., Jun, D., 2006. Municipal solid waste management challenges in developing countries - Kenyan case study. Waste Manage. 26, 92100. https://doi.org/10.1016/j.wasman.2005.03.007.

Kurian, J., Esakku, S., Nagendran, R., Visvanathan, C., 2005. A Decision Making Tool for Dumpsite Rehabilitation in Developing Countries. In: Proceedings Sardinia 2005, Tenth International Waste Management and Landfill Symposium S. Margherita Di Pula, Cagliari, Italy; 3 - 7 October 2005, pp. 1-8.

La Cour Jansen, J., Spliid, H., Hansen, T.L., Svärd, Å., Christensen, T.H., 2004. Assessment of sampling and chemical analysis of source-separated organic household waste. Waste Manage. 24, 541-549. https://doi.org/10.1016/j. wasman.2004.02.013.

Longe, E.O., Balogun, M.R., 2010. Groundwater quality assessment near a municipal landfill, Lagos, Nigeria. Res. J. Appl. Sci. Eng. Technol. 2, 39-44.

Minghua, Z., Xiumin, F., Rovetta, A., Qichang, H., Vicentini, F., Bingkai, L., Giusti, A. Yi, L., 2009. Municipal solid waste management in Pudong New Area, China. Waste Manage. 29, 1227-1233. https://doi.org/10.1016/j.wasman.2008.07.016.
Nagendran, R., Selvam, A., Joseph, K., Chiemchaisri, C., 2006. Phytoremediation and rehabilitation of municipal solid waste landfills and dumpsites: A brief review. Waste Manage. 26, 1357-1369. https://doi.org/10.1016/j.wasman.2006.05.003.

Nas, S.S., Bayram, A., 2008. Municipal solid waste characteristics and management in Gumushane, Turkey. Waste Manage. 28, 2435-2442. https://doi.org/10.1016/ j.wasman.2007.09.039.

Nnaji, C.C., 2015. Status of municipal solid waste generation and disposal in Nigeria. Manage. Environ. Qual. 26, 53. https://doi.org/10.1108/MEQ-08-2013-0092.

Odai, S.N., Mensah, E., Sipitey, D., Ryo, S., Awuah, E., 2008. Heavy Metals Uptake by Vegetables Cultivated on Urban Waste Dumpsites: Case Study of Kumasi, Ghana. Res. J. Environ. Toxicol. 2, 92-99.

Ojuri, O.O., 2015. Geotechnical characterization of some clayey soils for use as landfill liner. J. Appl. Sci. Environ. Manage. 19, 211-217. https://doi.org/ 10.4314/jasem.v19i2.6.

Ojuri, O.O., Adegoke, P.K., 2015. Geotechnical characteristics of synthetic municipal solid waste for effective landfill design. Int. J. Geomate 9, 1418-1427.

Ojuri, O.O., Akinwumi, I.I., Oluwatuyi, O.E., 2017. Nigerian lateritic clay soils as hydraulic barriers to adsorb metals. Geotechnical characterization and chemica compatibility. Environ. Prot. Eng. 43, 209-222. https://doi.org/10.5277/ epe170416.

Ojuri, O.O., Oluwatuyi, O.E., 2017. Strength and hydraulic conductivity characteristics of sand-bentonite mixtures designed as a landfill liner. Jordan J. Civ. Eng. 11, 614-622.

Ojuri, O.O., Taiwo, O.A., Oluwatuyi, O.E., 2016. Heavy metal migration along a rura highway route: ilesha-akure roadside soil, southwestern, Nigeria. Glob. NEST J $18,742-760$.

Olanrewaju, O.O., Ilemobade, A.A., 2009. Waste to wealth: a case study of the ondo state integrated wastes recycling and treatment project, Nigeria. Eur. J. Soc. Sci. $8,7-16$.

Oluwatuyi, O.E., Ojuri, O.O., 2017. Environmental performance of lime-rice husk ash stabilized lateritic soil contaminated with lead or naphthalene. Geotech. Geol. Eng. 35, 2947-2964. https://doi.org/10.1007/s10706-017-0294-9.

Oyelami, A.C., Aladejana, J.A., Agbede, O.O., 2013. Assessment of the impact of open waste dumpsites on groundwater quality: a case study of the onibu-eja dumpsite, Southwestern Nigeria. Procedia Earth Planet. Sci. 7, 648-651. https:// doi.org/10.1016/j.proeps.2013.03.168.

Solomon, U.U., 2009. The state of solid waste management in Nigeria. Waste Manage. 29, 2787-2788. https://doi.org/10.1016/j.wasman.2009.06.030.

Sujauddin, M., Huda, S.M.S., Hoque, A.T.M.R., 2008. Household solid waste characteristics and management in Chittagong, Bangladesh. Waste Manage. 28, 1688-1695. https://doi.org/10.1016/j.wasman.2007.06.013.

Turan, N.G., Çoruh, S., Akdemir, A., Ergun, O.N., 2009. Municipal solid waste management strategies in Turkey. Waste Manage. 29, 465-469. https://doi.org/ 10.1016/j.wasman.2008.06.004.

World Health Organization, WHO, 2011. Guidelines for Drinking Water Quality. WHO, Geneva, p. 515.

Yuan, H., Shen, L., 2011. Trend of the research on construction and demolition waste management. Waste Manage. 31, 670-679. https://doi.org/10.1016/j. wasman.2010.10.030.

Zaïri, M., Ferchichi, M., Ismaïl, A., Jenayeh, M., Hammami, H., 2004. Rehabilitation of El Yahoudia dumping site, Tunisia. Waste Manage. 24, 1023-1034. https://doi. org/10.1016/j.wasman.2004.07.002. 